\title{
Relationship between health related locus of control and health behaviour among university students
}

\begin{abstract}
Objectives: The main goal of the study was to determine the relationship between health locus of control and students' chosen behaviours in respect of health protection.

Methods: The method of diagnostic survey was used for the study. The research tools were: the original questionnaire "Health behaviours" and the Multidimensional Health Locus of Control Scale adapted by Z. Juczyński.
\end{abstract}

Results: Complying with medical recommendations distinguished students with health problems in respect of mean values of MHLC in the dimension "chance" $(p<0,05)$.

Conclusion: An important element of improvement of public health is enhancement of efforts to form people's beliefs that it is right to look after one's health self-reliantly while using professionals' knowledge and experience when reasonable.

Keywords: health locus of control, health behavior, students, prophylaxis, health promotion, health psychology, general knowledge, experience, motivation, recognized values, set objectives, medical staff
Volume 3 Issue I - 2019

\author{
Aleksandra Słopiecka,' Magdalena Chrapek² \\ 'Faculty of Medicine and Health Sciences, The Jan Kochanowski \\ University, Poland \\ ${ }^{2}$ Department of Probability Theory and Statistics, The Jan \\ Kochanowski University, Poland
}

\begin{abstract}
Correspondence: Aleksandra Słopiecka, Instytut Zdrowia Publicznego,Wydział Lekarski i Nauk o Zdrowiu, Uniwersytet Jana Kochanowskiego w Kielcach, 25-317 Kielce, ul. IXWieków
\end{abstract} Kielc19, Poland, Email aleksaonet@op.pl

Received: January 18, 2018 | Published: January 16, 2019
Abbreviations: LOC, locus of control theory; MHLC, multidimensional health locus of control scale; CLOC, chance locus of control; PLOC, powerful other locus of control; M, arithmetic mean; SD, standard deviation

\section{Introduction}

In the literature on prophylaxis, health promotion and health psychology, a lot of consideration is given to health determinants, and particularly to lifestyle and practised health behaviour. Apparently an important goal of deliberation on that topic is to recognize the beliefs and motives for action of the healthy and unhealthy in the areas of life, which considerably influence the health. According to experts, people's attitudes in respect of health care are determined by a number of factors. Individual choice of the kind of adopted behaviour largely depends on the level of general knowledge, particularly knowledge on health protection, as well as experience, motivation, recognized values and set objectives. An important factor modifying an individual's activity in the process of maintaining full bio-psycho-social welfare is health-related locus of control. ${ }^{1}$ It is believed that undertaking actions in respect of physical and mental well-being largely depends on the expressed opinions on the influence of internal and external factors on health condition.

To measure the sense of responsibility for one's health, The Multidimensional Health Locus of Control Scale (MHLC) is applied. ${ }^{2}$ This research tool is an advanced version of the one-dimensional scale developed by K.A. Wallston, B.S. Wallston and R. DeVellis. ${ }^{3}$ The scale was based on the Locus of Control Theory (LOC) derived from the theory of social learning by J. Rotter. ${ }^{4}$ Polish adaptation of the test was made by Z. Juczyński. MHLC is a self-writing tool which contains 18 statements concerning generalized expectations in three dimensions of health locus of control: an Internal Locus of Control (ILOC), control by „powerful other” (Powerful Other Locus of Control - PLOC) and control by chance (Chance Locus of Control - CLOC). The first of the subscales reflects the beliefs that one should undertake initiative and actions for health protection as well as bear responsibility for its condition. In accordance with the LOC theory, an event is perceived as an effect of personal control and implementation of actions initiated by oneself. The second subscale, referred to as "others' influence", reveals domination of opinions concerning other people's influence on one's health. This means that the effects of actions aimed at health protection depend on other people, predominantly medical staff. The third dimension of the test refers to an individual's beliefs that health is primarily influenced by accidental events. This is interpreted in such a way that destiny and fate play a decisive role in health matters. The last two dimensions of the scale constitute an External Locus of Control. In the Polish version of MHLC a respondent can be given from 6 to 36 points in each of the three dimensions. Obtaining a high score in a given subscale indicates a strong belief that health condition is influenced by the related factor. The adopted principle is that the higher score, the stronger belief by the individual.

The scale MHLC has been used as a tool in many studies where the respondents were healthy persons or patients with certain health problems. ${ }^{5,6}$ Depending on the authors' assumptions and on the selection of the group of respondents, the mentioned test was used to determine health locus of control and to show the relationship between particular dimensions of the test and the selected variables. ${ }^{7}$ The executed projects also included attempts to evaluate individual differences in the quality of life of patients, ${ }^{8}$ studies in acceptance and implementation by patients of therapeutic recommendations or comparison of styles of coping with disease and occurring health problems and stress. ${ }^{9-11}$ In many studies, connections between health locus of control and indicators of health behaviour were searched for. ${ }^{12}$ An important issue discussed by experts was the use of research findings in designing health programmes and prophylaxis programmes as well as in health education, ${ }^{13,14}$ which plays a vital role in the formation of health-favourable behaviour. ${ }^{15}$ The main goal of the study was to determine the relationship between health locus of control and students' chosen behaviours in respect of health protection. In particular, an attempt was made to estimate the influence of students' beliefs concerning generalized expectations in the three dimensions of health locus control on regular medical appointments and complying with doctors' recommendations. 


\section{Methods}

The research included 630 students of the Faculty of Health Science at the Jan Kochanowski University of Humanities and Sciences in Kielce, aged 19 to 55. The group consisted of students of: Nursing - 397 persons, Midwifery - 50 persons, Public Health 87 persons and Emergency Medicine - 96 persons. The respondents were predominantly undergraduates $(89.5 \%)$, only $10.5 \%$ were postgraduate students. The method of diagnostic survey was used for the study. The research tools were: the original questionnaire "Health behaviours" and the Multidimensional Health Locus of Control Scale (MHLC-A) adapted by Z. Juczyński. The respondents were informed about the purpose and scope of the research, and they were given a written instruction on how to complete the questionnaires. The students participated in the research on an anonymous and voluntary basis. The original survey questionnaire was developed specifically for the purpose of the research and was used to learn the kind of chosen behaviours concerning health protection. The other research tool, i.e. the scale MHLC, was used in order to measure the kinds of health locus control among students. Statistical analyses were made by means of the statistical package $\mathrm{R}$ version 3.0.2. ${ }^{16}$ The following descriptive statistics were used: minimum, maximum, arithmetic mean (M), standard deviation (SD). Student's T-test was used to assess the significance of differences between mean values in the analysed groups, while the significance of difference between the data in their categories was estimated by test $\chi^{2}$. The difference adopted as statistically significant was $\mathrm{p}$-value $<0,05$.

\section{Methods}

There were 630 participants altogether, 573 females $(91.0 \%)$ and 57 males $(9.0 \%)$. The considerable predominance of women among the respondents resulted from bigger interest among women in education in the fields of study run in the Faculty of Health Science at the Jan Kochanowski University of Humanities and Sciences. Because of appreciable dispersion of respondents in respect of age and low percentage shares in particular age groups, the surveyed population was divided into three categories. Percentage shares in respective groups were as follows: $\leq 20$ years of age (44.8\%), 21-25 years $(36.8 \%), \geq 26$ years $(18.4 \%)$. The average age of the respondents was $24.1(\mathrm{SD}=7.8)$. Most students in the surveyed population, namely 518 persons $(82.2 \%)$ had completed secondary education, while $17.8 \%$ had a degree. A majority of $60.3 \%$ of the participants lived in rural areas and 39.7\% lived in the city. Among the respondents, the group of singles was predominant $(82.7 \%)$, represented mostly by unmarried females and males $(80.6 \%)$. The second biggest group was that of married people (17.3\%). An analysis of data on the financial status of the respondents shows that most of them (78.2\%) assessed it as average. Good or very good financial situation was confirmed by $14.4 \%$ of the people, while bad or very bad material status was admitted by $7.3 \%$ of the respondents. Particulars concerning the demographic and social situation of the surveyed population are shown in (Table 1).

Table 2 contains mean values of particular dimensions of MHLC obtained in Polish and American studies. An analysis of these data shows that the surveyed persons, in comparison with American students, obtained slightly higher values of arithmetic means in all the three subscales of the test. Taking into account only the results of the studies carried out in Poland, it was found that students of the Faculty of Health Science at the Jan Kochanowski University obtained lower values on the scale measuring internal control and influence of others. At the same time, the surveyed respondents presented a stronger belief that one's health is influenced by chance (Table 2).

Table I Demographic and social characteristics of the surveyed population

\begin{tabular}{|c|c|c|c|c|}
\hline \multirow{2}{*}{ Characteristic } & \multirow{2}{*}{\multicolumn{2}{|c|}{ Category }} & \multicolumn{2}{|c|}{ Surveyed population } \\
\hline & & & $\mathbf{N}$ & $\%$ \\
\hline \multirow{2}{*}{ Sex: } & female & & 573 & 91 \\
\hline & male & & 57 & 9 \\
\hline \multirow{5}{*}{ Age: } & & Total: & 630 & 100 \\
\hline & $\leq 20$ years old & & 282 & 44.8 \\
\hline & 21-25 years old & & 232 & 36.8 \\
\hline & $\geq 26$ years old & & 116 & 18.4 \\
\hline & & Total: & 630 & 100 \\
\hline \multirow{2}{*}{ Education: } & secondary & & 518 & 82.2 \\
\hline & $\begin{array}{l}\text { higher, including bachelo } \\
\text { degree }\end{array}$ & or's & 112 & 17.8 \\
\hline \multirow{4}{*}{$\begin{array}{l}\text { Place of } \\
\text { residence: }\end{array}$} & & Total: & 630 & 100 \\
\hline & country & & 380 & 60.3 \\
\hline & city & & 250 & 39.7 \\
\hline & & Total: & 630 & 100 \\
\hline \multirow{5}{*}{ Marital status: } & single & & 508 & 80.6 \\
\hline & married & & 109 & 17.4 \\
\hline & widow, widower & & 2 & 0.3 \\
\hline & divorced & & 9 & 1.4 \\
\hline & domestic partner & & 2 & 0.3 \\
\hline \multirow{5}{*}{ Material status: } & & Total: & 630 & 100 \\
\hline & very good or good & & 91 & 14.4 \\
\hline & medium & & 493 & 78.3 \\
\hline & bad or very bad & & 46 & 7.3 \\
\hline & & Total: & 630 & 100 \\
\hline
\end{tabular}

Table 2 A comparison of MHLC (M $\pm S D)$ results obtained by the surveyed group with groups of Polish and American students

\begin{tabular}{llll}
\hline Sense of health control & $\begin{array}{l}\text { Surveyed } \\
\text { group }\end{array}$ & $\begin{array}{l}\text { Polish } \\
\text { students }\end{array}$ & $\begin{array}{l}\text { American } \\
\text { students }\end{array}$ \\
\hline & $(\mathrm{n}=630)$ & $\left(\mathrm{n}=97^{\mathrm{a}}\right)$ & $\left(\mathrm{n}=749^{\mathrm{a}}\right)$ \\
Internal control (ILOC) & $27,1 \pm 4,5$ & $28,61 \pm 3,73$ & 26,68 \\
Powerful others (PLOC) & $18,2 \pm 5,25$ & $18,76 \pm 4,19$ & 17,87 \\
Chance (CLOC) & $16,9 \pm 5,5$ & $15,65 \pm 5,12$ & 16,72 \\
\hline
\end{tabular}

aSource: Juczyński Z. Narzędzia pomiaru w promocji zdrowia i psychologii zdrowia. Pracownia Testów Psychologicznych PTP. 200I.

The survey questionnaire contains a question about the occurrence of diseases and health problems recognized by a doctor. The data given in Table 3 show that 329 persons ( $52.2 \%$ of the total) confirmed the fact of occurrence of health-related problems. The other respondents, i.e. 301 students $(47.8 \%)$ gave a negative response to the question. In both 
surveyed groups, the highest scores in the three subscales of MHLC were obtained in the first dimension of the test (internal health locus control), and the lowest in the dimension of chance. The occurrence of health problems was different among respondents in respect of mean values of MHLC in the dimension of chance $(\mathrm{p}<0.05)$. This means that a stronger belief in the influence of chance on one's health was declared by students with health problems. No significant variation of results was found within the other two subscales of MHLC, i.e. internal control and powerful others (Table 3).

Table 3 Occurrence of health problems and sense of health locus of control in surveyed people

\begin{tabular}{|c|c|c|c|c|c|c|c|c|c|c|}
\hline \multirow{3}{*}{ Sense of health control } & \multicolumn{8}{|c|}{ Surveyed group } & \multirow{3}{*}{$\begin{array}{l}\text { Statistics in } \\
\text { T-test }\end{array}$} & \multirow{3}{*}{$\mathbf{p}$} \\
\hline & \multicolumn{4}{|c|}{ with health problems $(n=329)$} & \multicolumn{4}{|c|}{ with no health problems $(n=301)$} & & \\
\hline & $\min$ & $\max$ & $\mathbf{M}$ & SD & $\min$ & $\max$ & M & SD & & \\
\hline Internal control (ILOC) & 10 & 36 & 26,8 & 4,6 & 14 & 36 & 27,5 & 4,6 & 1,9 & 0,06 \\
\hline Powerful others (PLOC) & 6 & 33 & 18,2 & 5,1 & 6 & 33 & 18,1 & 5,3 & 0,08 & 0,946 \\
\hline Chance (CLOC) & 6 & 34 & 17,5 & 5,5 & 6 & 32 & 16,3 & 5,4 & 2,7 & 0,007 \\
\hline
\end{tabular}

Health problems mentioned by the students were grouped, in accordance with the International Statistical Classification of Diseases and Related Health Problems. 10th Revision, into 8 categories. ${ }^{17}$ The structure of diseases and health problems is shown in Table 4. Among the surveyed, the biggest group of students suffered from diseases of the musculoskeletal system and connective tissue (14.4\%), diseases of the digestive system $(13.7 \%)$ and diseases of the genitourinary system $(10.6 \%)$. The same percentage of the surveyed, i.e. $10.3 \%$ each, reported occurrence of diseases of the respiratory system and diseases of the circulatory system. Endocrine, nutritional and metabolic diseases were indicated by $4.6 \%$ of the respondents, while diseases of the nervous system were mentioned by $4.4 \%$ of the people. A separate category of the analysed characteristic was "other diseases", where people suffering from skin diseases and those with sight or hearing problems were qualified ( $6.0 \%$ of the people). It is noteworthy that numbers and percentage shares of the surveyed, when added up, do not equal the total, since 103 students pointed to more than one health problem, some of them mentioning from 2 to 4 single diseases (Table 4).

According to state-of-the-art medical knowledge, one's health status largely depends on one's lifestyle and behaviour which to a great extent are connected with health protection. In the case of occurrence of health problems, the prerequisite for check-up, estimation of progress of a disease or its consequences and the monitoring of the effects of therapy is reporting to medical appointments and complying with doctor's recommendations. As stated before, 329 respondents in the surveyed population had health problems. Out of them, 126 persons did not report regularly for check-ups. This particular group, in comparison with the people who systematically visited the doctor, was characterized by lower scores in all the subscales of MHLC. The biggest difference in obtained results, however, appeared in respect of external health locus of control. It can be inferred, therefore, that people reporting regularly for medical check-ups were characterized by a stronger belief that their behaviours and actions influenced their health. However, no statistically significant differences were found in respect of mean results on each subscale of the test MHLC (Table 5).

Table 4 Kinds of health problems occurring in surveyed people

\begin{tabular}{lll}
\hline \multirow{2}{*}{ Kinds of diseases and health problems } & \multicolumn{2}{l}{ Surveyed population } \\
\cline { 2 - 3 } & $\mathbf{N}$ & $\mathbf{\%}$ \\
\hline No health problems reported & 301 & 47.8 \\
$\begin{array}{l}\text { Diseases of the musculoskeletal system and } \\
\text { connective tissue }\end{array}$ & 91 & 14.4 \\
Diseases of the digestive system & 86 & 13.7 \\
Diseases of the genitourinary system & 67 & 10.6 \\
Diseases of the respiratory system & 65 & 10.3 \\
Diseases of the circulatory system & 65 & 10.3 \\
Endocrine, nutritional and metabolic diseases & 29 & 4.6 \\
Diseases of the nervous system & 28 & 4.4 \\
Other diseases & 38 & 6 \\
Total* & 630 & 100 \\
\hline
\end{tabular}

*The sum of numbers and percentage shares does not equal the total.

In the next question of the questionnaire, addressed only to the students with health problems, they were asked to confirm if they complied with doctor's instructions. 221 respondents gave a positive answer (67.2\% of the analysed group). Nearly every third participant with health problems $(32.8 \%)$ denied complying with medical recommendations. MHLC results in two dimensions of the scale. i.e. "internal control" and "powerful others" were slightly higher in the group of people following doctor's instructions. However, no statistically significant connections were found between the values in those subscales and the studied category (Table 6). On the other hand, a significant difference was found in the dimension "powerful others" in respect of following doctor's recommendations by students with health problems $(\mathrm{p}<0.05)$.

Table 5 Reporting of students with health problems for regular check-ups and health locus of control

\begin{tabular}{|c|c|c|c|c|c|c|c|c|c|c|}
\hline \multirow{3}{*}{ Sense of health control } & \multicolumn{8}{|c|}{ Surveyed people with health problems } & \multirow{3}{*}{ Test statistics in T-test } & \multirow{3}{*}{$\mathbf{p}$} \\
\hline & \multicolumn{4}{|c|}{ did not report to doctor $(n=126)$} & \multicolumn{4}{|c|}{ reported to doctor $(n=203)$} & & \\
\hline & $\min$ & $\max$ & $\mathbf{M}$ & SD & $\min$ & $\max$ & $\mathbf{M}$ & SD & & \\
\hline Internal control (ILOC) & 10 & 36 & 26,2 & 4,76 & 13 & 36 & 27,1 & 4,40 & 1,796 & 0,074 \\
\hline Powerful others (PLOC) & 6 & 31 & 17,8 & 5,21 & 6 & 33 & 18,4 & 5,05 & 1,035 & 0,302 \\
\hline Chance (CLOC) & 7 & 29 & 17,1 & 5,03 & 6 & 34 & 17,7 & 5,72 & 1,075 & 0,283 \\
\hline
\end{tabular}


Table 6 Compliance with medical recommendations by people with health problems and health locus of control

\begin{tabular}{|c|c|c|c|c|c|c|c|c|c|c|}
\hline \multirow{3}{*}{ Sense of health control } & \multicolumn{8}{|c|}{ Surveyed people with health problems } & \multirow{3}{*}{ Test statistics in T-test } & \multirow{3}{*}{$\mathbf{p}$} \\
\hline & \multicolumn{4}{|c|}{ did not follow instructions $(n=108)$} & \multicolumn{4}{|c|}{ followed instructions $(n=221)$} & & \\
\hline & $\min$ & $\max$ & $\mathbf{M}$ & SD & $\min$ & $\max$ & $\mathbf{M}$ & SD & & \\
\hline Internal control (ILOC) & 10 & 36 & 26,1 & 4,86 & 13 & 36 & 27,1 & 4,37 & 1,847 & 0,066 \\
\hline Powerful others (PLOC) & 6 & 30 & 17,3 & 4,94 & 6 & 33 & 18,6 & 5,15 & 2,290 & 0,023 \\
\hline Chance (CLOC) & 7 & 33 & 17,5 & 5,13 & 6 & 34 & 17,5 & 5,64 & 0,011 & 0,992 \\
\hline
\end{tabular}

\section{Discussion}

Knowledge on health behaviours is used in therapeutic processes, in organization of health programmes, in prophylaxis and in many initiatives undertaken in the field of public health. In order to increase the effectiveness of performed projects, determinants of people's behaviours in particular life situations are more and more often taken for analysis. Recognition of the relations between these determinants enables the planning of optimum actions, which are to enhance the favourable and to reduce the adverse factors influencing individuals' motivation and attitudes with respect to health protection.

Relations between health locus of control and health behaviours or other mental and physical characteristics have been confirmed in a number of publications. Beliefs concerning generalized expectations in the three dimensions of health locus of control were estimated in different groups of patients suffering from a specific disease. ${ }^{18}$ Experts report that people suffering from chronic diseases (mental) usually are characterized by predominance of external locus of control (mostly influence of others) over internal LOC. ${ }^{19}$ According to B.A. Kulig, the tendency may result from change of locus of control originating as a consequence of a long-lasting (often incurable) disease, or of a worse physical and mental condition of people convinced of overwhelming influence of external factors on their health status. ${ }^{20}$ Other studies found predominance of internal health locus of control in patients. ${ }^{21}$ Discussing the issue in question, experts report that the formation of beliefs is a complex process, subject to changes over time and the impact of many factors. Therefore, it is difficult to identify unequivocally a set of characteristics determining opinions of patients. Considering only the elements connected with the conduct of the research, the values of the test MHLC are influenced by: the size and method of selection of the surveyed population, demographic and social status of the surveyed group (e.g. age, sex, education, place of residence, marital status), kind of disease, course and prognosis of the disease, respondents' level of knowledge on health protection and many other mental and physical characteristics of the surveyed persons. Without additional information about the mentioned characteristics it is difficult to make a detailed comparative analysis of the given data.

The scale MHLC was also used to survey persons meeting specific criteria of selection for the research group. Most often they concerned the kind of job, place of residence or education and other indices. ${ }^{22,23}$ An important finding of the performed study was the ascertainment that there are significant connections of LOC with people's health behaviours such as: taking stimulants, ${ }^{24}$ nutrition habits, ${ }^{25}$ physical activity or participation in prophylactic examinations. ${ }^{26,27}$ In the published studies, the authors usually showed connections of healthfavourable behaviours with internal LOC, and health-adverse behaviours with external locus of control (influence of chance or powerful others). ${ }^{28}$ It has been accepted that internal locus of control is conducive to taking health-favourable actions, even including alternative medicine. ${ }^{29}$

The test MHLC was also used for research among students of a medical university, most of whom were found to have internal health locus of control. ${ }^{30}$ Experts assume that such locus of control favours maintaining a better health condition. However, as K. Fiszer and T. Sobów see it, workers in medical jobs with internal LOC may not rise to the responsibility they bear, which leads to avoiding independent decisions. As a result of inability to effectively fulfil their professional duties, there appear failures and problems in the workplace. The authors of the research also presented a list of factors influencing the location of LOC, which included: age, chosen field of study, sense of responsibility and experience accumulated in the lifetime. ${ }^{31}$ Estimation of locus of control was also carried out among nurses. According to I. Malinowska-Lipien, despite the high values of internal dimension of MHLC, the surveyed women did not manifest health-favourable prophylactic behaviours, and their knowledge on the main risk factors for cervical carcinoma was assessed as unsatisfactory. ${ }^{32}$ Also in the opinion of V. Jachimowicz, surveyed nurses displayed a high degree of internal health locus of control, and yet a large percentage of the respondents were current or former smokers $(42.6 \%)$. The surveyed women claimed that smoking gave them pleasure, relieved tension, and part of them did not reflect upon motives for their smoking. ${ }^{33}$ Thus, medical education and a strong sense of one's responsibility for health did not prompt the nurses to prefer health-favourable behaviour.

The author's own research reveals that internal and external (other people) health locus of control in respondents who systematically report for check-ups and comply with doctor's recommendations are slightly higher compared to the group of people not following doctor's instruction. Supposedly it was the belief about the impact of their own actions and other people's actions on health that was the origin of health-favourable behaviours in this group. It is alarming that a large share of students with health problems, despite their high scores concerning internal control, neither reported to doctor nor did they follow specialist's recommendations. Perhaps such behaviour resulted from a strong sense of having knowledge, acquired in the course of education in the chosen field, sufficient for self-care. There is, however, a fear that students may wrongly overestimate the acquired medical knowledge and nursing skills and burden themselves with excessive responsibility for their health. In practice it also happens that medical workers falsely declare having specific knowledge in the area of health protection.

Respondents' reluctance to use professional help probably resulted from the belief that other people had a weak influence on health condition, since the respondents obtained low scores in respect of 
external health locus of control in other people. Experts' opinion is that the optimum configuration of characteristics is obtaining high scores in the test MHLC both in the external dimension and in other people's influence. K. Kurowska and I. Siekierko claim that in such cases patients readily comply with therapeutic recommendations and mobilize themselves to take action. Simultaneous occurrence of strong conviction about other people's and one's own behaviour's impact on one's health status reduce the likeliness of a tendency to correct therapy without previous consultation with medical staff. ${ }^{34} \mathrm{~A}$ similar opinion was also expressed by Z. Juczyński who said that "it is easier to implement a change of one's behaviour (a diet, giving up smoking), if a strong conviction about the influence of others (a doctor recommending diet) coincides with internal locus mobilizing for effective action". ${ }^{35}$ With reference to the above opinions, it should be concluded that the identification of the causes of occurrence of assumptions about little influence of others among students of nursing, midwifery, emergency medicine and public health is a problem deserving further research. In such cases it is also important to assess readiness of medical students to fulfil the role of educators in their future careers.

In conclusion, opinions of individuals on health determinants have a real influence on the readiness to take actions for health protection and an impact on physical and mental condition. It seems that an important element of improvement of public health is enhancement of efforts to form people's beliefs that it is right to look after one's health self-reliantly while using professionals' knowledge and experience when reasonable. The above recommendation should also apply to medical students and health service workers.

\section{Conclusion}

a) The study proves that students with health problems manifested significantly higher sense of the impact of chance on health than the healthy group of respondents.

b) No significant relationship was found between sick students' reporting for regular check-ups and health locus of control.

c) Respondents complying with doctor's recommendations had a significantly higher locus of control connected with other people's influence than the students who did not follow doctor's instructions.

d) It has to be assumed that the increase in opinions about other people's influence on health condition will be accompanied by students' readiness to undertake actions initiated and controlled by professionals.

\section{Acknowledgments}

None.

\section{Conflict of interests}

The authors state that they have no conflicts of interest.

\section{Funding}

This research was founded by The Jan Kochanowski University in Kielce, project number 433/W/10.

\section{References}

1. Janowski K, Kurpas D, Kusz J, et al. Health-Related Behavior. Profile of health locus of control and acceptance of illness in patients suffering from chronic somatic diseases. PLOS ONE. 2013;8(5):e63920.

2. Wallston, KA. The validity of the Multidimensional Health Locus of Control Scales. Journal of Health Psychology. 2005;10(5):623-631.

3. Wallston KA, Wallston BS, DeVellis R. Development of the multidimensional health locus of control (MHLC) scales. Health Educ Monogr. 1978;6(2):160-170.

4. Rotter JB. Generalized expectancies for internal versus external control of reinforcement. Psychological Monographs: General and Applied. 1966;80(1):1-28.

5. Grotz M, Hapke U, Lampert T, et al. Health locus of control and health behavior: Results from a nationally representative survey. Psychology, Health \& Medicine. 2011;16(2):129-140.

6. Pucheu S, Consoli SM, D'Auzac C, et al. Do health casual attributions and coping strategies act as moderators of quality of life in peritoneal dialysis patients? J Psychosom Res. 2004;56(3):317-322.

7. Armitage CJ, Norman P, Conner M. Can the Theory of Planned Behavior mediate the effects of age, gender and multidimensional health locus of control? Br J Health Psychol. 2002;7(Part 3):299-316.

8. Kostka T, Jachimowicz V. Relationship of quality of life to dispositional optimism, health locus of control and self-efficacy in older subjects living in different environments. Qual Life Res. 2010;19(3):351-361.

9. O'Hea EL, Grothe KB, Bodenlos JS, et al. Predicting medical regimen adherence: the interactions of health locus of control beliefs. $J$ Health Psychol. 2005;10(5):705-717.

10. Mućko P, Kokoszka A, Skłodowska Z. The comparison of coping styles, occurrence of depressive and anxiety symptoms, and locus of control among patients with diabetes type 1 and type 2. Diabetologia Praktyczna. 2005;6(5):240-249.

11. Roddenberry A, Renk K. Locus of control and self - efficacy: Potential mediators of stress, illness and utilization of health services in college students. Child Psychiatry Hum Dev. 2010;41:353-370.

12. Orejudo HS, Froján PMX, Malo AC. Illness behavior: prediction by symptoms, the Grossarth-Maticek and Eysenck Personality Types, neuroticism, life events, coping, health locus of control, social support, and attribution style. Span J Psychol. 2007;10(2):388-98.

13. Adolfsson B, Andersson I, Elofsson S, et al. Locus of control and weight reduction. Patient Educ Couns. 2005;56(1):55-61.

14. Cardenas DD, Hoffman JM, Kelly E, et al. Impact of a urinary tract infection educational program in persons with spinal cord injury. The Journal Of Spinal Cord Medicine. 2004;27(1):47-54.

15. Potdar S, Lakshminarayan N, Goud Reddy S. Relationship of Locus of control with Plaque and Gingival status before and after Oral Health Education in a group of college students - An experimental study. International Journal Of Dental Hygiene. 2014;13(1):42-48.

16. R Core Team. R: A language and environment for statistical computing. R Foundation for Statistical Computing. 2013.

17. World Health Organization. International Statistical Classification of Diseases and Related Health Problems. 10th Revision. 2010:3-30.

18. O'Hea EL, Bodenlos JS, Moon S, et al. The multidimensional health locus of control scales: testing the factorial structure in sample of African American medical patients. Ethn Dis. 2009;19(2):192-198.

19. Hutcheson C, Fleming MP, Martin CR. An examination and appreciation of the dimensions of locus of control in psychosis: issues and relationships between constructs and measurement. $J$ Psychiatr Ment Health Nurs. 2014;21(10):906-916. 
20. Kulig BA. Health locus of control, knowledge of illness and perception of recovery aiding factors among patients with bipolar affective disorder. Post Psychiatr Neurol. 2013;22(4):243-249.

21. Opuchlik K, Wrzesińska M, Kocur J. The assessment of the level of coping style and health locus of control in patients with coronary heart disease and hypertension. Psychiatr Pol. 2009;43(2):235-245.

22. Steptoe A, Wardle J. Health behavior, risk awareness and emotional well-being in students from Eastern Europe and Western Europe. Soc Sci Med. 2001;53(12):1621-1630.

23. Świerblewska E, Korzon-Burakowska A, Adamska K, et al. Effect of education level on diabetes control and quality of life in insulin-treated type 2 diabetic patients. Diabetologia Praktyczna. 2010;11(2):46-53.

24. Kuwahara A, Nishino Y, Ohkubo T, et al. Reliability and validity of the Multidimensional Health Locus of Control Scale in Japan: relationship with demographic factors and health-related behavior. Tohoku J Exp Med. 2004;203(1):37-45.

25. Norman P. Health locus of control and health behavior: an investigation into the role of health value and behavior - specific efficacy beliefs. Pers Indiv Differ. 1995;18(2):213-218.

26. Guszkowska M, KukA. Health locus of control of polish undergraduates: gender, faculty and type of physical activity differences. Baltic Journal of Health and Physical Activity. 2012;4(3):189-196.

27. Holm CJ, Frank DI, Curtin J, et al. Health beliefs, health locus of control, and women Health beliefs, health locus of control, and women's mammography behavior. Cancer Nurs. 1999;22(2):149-156.
28. Helmer SH, Krämer A, Mikolajczyk RT. Health-related locus of control and health behaviour among university students in North Rhine Westphalia. BMC Research Notes. 2012;5:703.

29. Sasagawa M, Martzen MR, Kelleher WJ, et al. Positive correlation between the use of complementary and alternative medicine and internal health locus of control. Explore: The Journal of Science and Healing. 2008;4(1):38-41.

30. Mojs E, Wójciak RW, Kleka P. Internal locus of control of health and smoking cigarettes in young adults. Prz Lek. 2006;63(10): 1054-1056.

31. Fiszer K, Sobów T. Relation between health locus of control and depression among students of a medical college. Med Ogólna. 2013;19(3):294-299.

32. Malinowska-Lipień I, Gniadek A, Doros J. Cervical cancer prevention in a selected group of nurses on the background of the Multidimensional Health Locus of Control Scale (MHLC). Zdr Publ. 2012;122(1):29-34.

33. Jachimowicz V, Gawłowicz K, Juszczak K. The sense of self-efficiency and the locus of health control in respect of smoking among nurses. Prz Lek. 2011;68(10):879-882.

34. Kurowska K, Siekierska I. Disease acceptance versus health locus of control in people after nephrectomy because of the kidney cancer. Pielęg Chir Angiol. 2013;2:65-71.

35. Juczyński Z. Narzędzia pomiaru $w$ promocji zdrowia $i$ psychologii zdrowia. Pracownia Testów Psychologicznych PTP. 2001. 